Keywords: matrix metalloproteinase-8; invasion; proteinase web; transforming growth factor- $\beta 1$; vascular endothelial growth factor-C; squamous cell carcinoma; tongue neoplasms

\title{
The interplay of matrix metalloproteinase-8, transforming growth factor- $\beta 1$ and vascular endothelial growth factor-C cooperatively contributes to the aggressiveness of oral tongue squamous cell carcinoma
}

Pirjo Åström ${ }^{\star} 1,2,3$, Krista Juurikka ${ }^{1,2,17}$, Elin S Hadler-Olsen ${ }^{4,17}$, Gunbjørg Svineng ${ }^{4}$, Nilva K Cervigne ${ }^{5,6}$, Ricardo D Coletta ${ }^{6}$, Juha Risteli ${ }^{1,2,3,7,8}$, Joonas H Kauppila ${ }^{1,2,3,9}$, Sini Skarp ${ }^{10,11,12}$, Samuel Kuttner ${ }^{13,14}$, Ana Oteiza ${ }^{13,14}$, Meeri Sutinen ${ }^{1,2,3,18}$ and Tuula Salo $1,2,3,15,16,18$

Background: Matrix metalloproteinase-8 (MMP-8) has oncosuppressive properties in various cancers. We attempted to assess MMP-8 function in oral tongue squamous cell carcinoma (OTSCC).

Methods: MMP-8 overexpressing OTSCC cells were used to study the effect of MMP-8 on proliferation, apoptosis, migration, invasion and gene and protein expression. Moreover, MMP-8 functions were assessed in the orthotopic mouse tongue cancer model and by immunohistochemistry in patient samples.

Results: MMP-8 reduced the invasion and migration of OTSCC cells and decreased the expression of MMP-1, cathepsin-K and vascular endothelial growth factor-C (VEGF-C). VEGF-C was induced by transforming growth factor- $\beta 1$ (TGF- $\beta 1$ ) in control cells, but not in MMP-8 overexpressing cells. In human OTSCC samples, low MMP-8 in combination with high VEGF-C was an independent predictor of poor cancer-specific survival. TGF- $\beta 1$ treatment also restored the migration of MMP-8 overexpressing cells to the level of control cells. In mouse tongue cancer, MMP-8 did not inhibit metastasis, possibly because it was eliminated in the peripheral carcinoma cells.

Conclusions: The suppressive effects of MMP-8 in OTSCC may be mediated through interference of TGF- $\beta 1$ and VEGF-C function and altered proteinase expression. Together, low MMP-8 and high VEGF-C expression have strong independent prognostic value in OTSCC.

Matrix metalloproteinases (MMPs) are one of the key players in cancer progression. MMPs degrade tissue barriers and enable tumour invasion and metastasis (Egeblad and Werb, 2002). However, it has become evident that the contribution of MMPs is far more diverse (Overall and Kleifeld, 2006). Matrix metalloproteinase- 8 was among the first MMPs reported to have tumour-suppressive features (Balbin et al, 2003). Originally identified in neutrophils, MMP-8 is produced by various cells (Van Lint and Libert, 2006), including oral tongue squamous cell carcinoma (OTSCC) cells (Moilanen et al, 2002).

\footnotetext{
*Correspondence: Dr P Åström; E-mail: pirjo.astrom@oulu.fi

${ }^{17}$ These authors contributed equally to this work.

${ }^{18}$ These authors contributed equally to this work.
}

Received 27 January 2017; revised 5 July 2017; accepted 6 July 2017; published online 3 August 2017

(C) 2017 Cancer Research UK. All rights reserved 0007-0920/17 
The oncosuppressive effects of MMP-8 have been reported in malignancies such as melanoma (Gutiérrez-Fernández et al, 2008; Palavalli et al, 2009), skin (Balbin et al, 2003), breast (Agarwal et al, 2003; Montel et al, 2004; Decock et al, 2008; Soria-Valles et al, 2014), lung (Gutiérrez-Fernández et al, 2008) and tongue carcinomas (Korpi et al, 2008), but contrary evidence also exists (Stadlmann et al, 2003; Väyrynen et al, 2012).

The role of MMP-8 in head and neck squamous cell carcinomas is contradictory (Korpi et al, 2008; Pradhan-Palikhe et al, 2010; Mäkinen et al, 2012; Nurmenniemi et al, 2012). Head and neck squamous cell carcinomas are heterogeneous regarding their epidemiology, aetiology and survival rates (Rethman et al, 2010). Our previous study showed that MMP-8 expression by tumour cells improves patient survival, and MMP-8 protects mice from carcinogen-induced OTSCC (Korpi et al, 2008). There are few studies demonstrating the effects of MMP-8 in cancers at the cellular and molecular levels (Gutiérrez-Fernández et al, 2008; Pellinen et al, 2012; Thirkettle et al, 2013; Soria-Valles et al, 2014; Decock et al, 2015). We thus examined the action of MMP-8, a tumoursuppressive proteinase with promising diagnostic value in OTSCC.

\section{MATERIALS AND METHODS}

Cells. Human OTSCC cell lines HSC-3 (Japan Health Sciences Foundation, Tokyo, Japan), SCC-15 and SCC-25 (American Type Culture Collection, Manassas, VA, USA) were cultured as described (Bitu et al, 2013). The cells were transduced with lentiviral particles containing MMP8 (GenBank: NM_002424.2) (MMP-8 + cells) or a non-coding control sequence (Amsbio, Abingdon, UK) (control cells) and selected by puromycin to obtain stable, polyclonal cell lines. In case of HSC-3 cells, two transfection clones were done. Cathepsin K-silenced (shCat-K) HSC-3 cells were previously described (Bitu et al, 2013). Short tandem repeat profiling of the cells was done by IdentiCell (Aarhus, Denmark). Mycoplasma infection was excluded by regular testing with MycoTrace PCR Detection Kit (PAA Laboratories GmbH, Cölbe, Germany). To collect conditioned media, the cells were washed with PBS prior to adding Opti-MEM (Life Technologies, Carslbad, CA, USA). Recombinant human TGF- $\beta 1 \quad\left(10 \mathrm{ng} \mathrm{ml}^{-1}\right)$ (R\&D System, Minneapolis, MN, USA) was included where indicated. After $24 \mathrm{~h}$, small amounts of media were taken for zymography before adding cOmplete Tablets proteinase inhibitors (SigmaAldrich, St Louis, MO, USA). The media were clarified by centrifugation. The cells were harvested in elution buffer $(50 \mathrm{~mm}$ Tris-HCl, $10 \mathrm{~mm} \mathrm{CaCl}_{2}, 150 \mathrm{~mm} \mathrm{NaCl}, 0.05 \%$ (v/v) Brij-35 (SigmaAldrich) with cOmplete Tablets proteinase inhibitors (SigmaAldrich) at $4{ }^{\circ} \mathrm{C}$ overnight and clarified by centrifugation.

Polymerase chain reaction. Total RNA was extracted from subconfluent cultures with TRI Reagent (Sigma-Aldrich) according to the product protocol and transcribed into cDNA by SuperScript III First-Strand Synthesis System (Life Technologies). Semiquantitative PCR reactions were conducted with AmpliTaq Gold DNA Polymerase (Life Technologies). Primers are described in the Supplementary Methods. The annealing temperature was $64^{\circ} \mathrm{C}$ (MMP8) and $54^{\circ} \mathrm{C}(A C T B)$.

Quantitative RT-PCR. Total RNA was isolated using TRIzol Reagent (Life Technologies) according to the manufacturer's protocol. First-strand cDNAs were synthesised from $2 \mu \mathrm{g}$ of DNase-treated RNA using the SuperScript II Reverse Transcription Kit (Life Technologies). Diluted cDNA (1:3) was used to perform qRT-PCR using the SYBR Green PCR Master Mix (Applied Biosystems, Foster City, CA, USA) in a 7900 RT-PCR System (Applied Biosystems). Primers are described in the Supplementary Methods. The PCR cycles were $95^{\circ} \mathrm{C}$ for $10 \mathrm{~min}, 40$ cycles of $95^{\circ} \mathrm{C}$ for $15 \mathrm{~s}$ and $60^{\circ} \mathrm{C}$ for $1 \mathrm{~min}$. Each reaction was performed in triplicate and individually analysed. The results were calculated by using the $2^{-\triangle \triangle \mathrm{Ct}}$ relative quantification method.

Western blot. Media and cell proteins were analysed by western blot as described (Korpi et al, 2008) in reducing (vascular endothelial growth factor-C (VEGF-C), MMP-14, N-cadherin and vimentin antibodies) or non-reducing (all other antibodies) conditions. Where indicated, the conditioned medium $(20 \mu \mathrm{g}$ protein) was incubated for $2 \mathrm{~h}$ at $37^{\circ} \mathrm{C}$ with or without $1 \mathrm{~mm} 4$ aminophenylmercuric acetate (APMA) before analysis. The primary antibodies were rabbit anti-MMP-8 \#ABT38 (Millipore, Billerica, MA, USA), $1 \mu \mathrm{g} \mathrm{ml}^{-1}$, mouse anti-TGF- $\beta 1$ MAB240 (R\&D systems), $2 \mu \mathrm{g} \mathrm{ml}^{-1}$, mouse anti-E-cadherin \#13-1700 (Invitrogen, Carlsbad, CA, USA), 1:1000, rabbit anti-Slug C19G7 (Cell Signaling Technologies Inc., Danvers, MA, USA), 1:1000, mouse anti-N-cadherin 3B9 (Invitrogen), $1 \mu \mathrm{g} \mathrm{ml}^{-1}$, mouse antivimentin V9 (DAKO A/S, Glostrup, Denmark), 1:750, goat antiVEGF-C AF752 (R\&D Systems), $0.2 \mu \mathrm{g} \mathrm{ml}^{-1}$, rabbit anti-MMP-1 AB8105 (Chemicon International, Temecula, CA, USA), $1 \mu \mathrm{g} \mathrm{ml}^{-1}$, and mouse anti-MT1-MMP LEM-2/15.8 (Millipore), $1 \mu \mathrm{g} \mathrm{ml}^{-1}$. Equal sample loading was controlled by Coomassie Blue staining of the gel before blotting (medium samples) or mouse $\beta$-actin ab8226 (Abcam, Cambridge, UK), $0.5 \mu \mathrm{g} \mathrm{ml}^{-1}$ immunoblotting (cell extracts). The secondary antibodies were rabbit antimouse antibody E0354, swine anti-rabbit antibody E0353 (DAKO A/S) and horse anti-goat antibody BA9500 (Vector Laboratories Inc., Burlingame, CA, USA), 1:1000. Pierce ECL Western Blotting Substrate (Thermo Scientific, Waltham, MA, USA) was used for visualisation. Band intensities were quantified by Fiji software (Schindelin et al, 2012).

Radioimmunoassay. $1.5 \times 10^{6}$ control and MMP- $8+$ HSC-3 cells (three different cell passages) were seeded onto $55 \mathrm{~cm}^{2}$ plates. The cells were washed with PBS and $6 \mathrm{ml}$ of Opti-MEM (Life Technologies) was added and collected after 5 days. Equal volumes of the three media were pooled and concentrated $(4 \times)$. Carboxyterminal telopeptide of type I collagen (ICTP) (Risteli et al, 1993) was measured using ICTP-RIA kit (Orion Diagnostica Oy, Espoo, Finland) according to the manufacturer's instructions.

Organotypic 3D leiomyoma cell invasion assay. Human leiomyoma tissue samples were obtained during routine surgeries after obtaining written consent of the donors. The study was approved by the Ethics Committee of the Oulu University Hospital (\#35/ 2014 , 04.01.2016). The invasion assays were performed as described (Nurmenniemi et al, 2009) using $7 \times 10^{5}$ control and MMP-8 + HSC-3, SCC-25 and SCC-15 cells. After 14 days, the tissues were processed into histological samples (Teppo et al, 2013).

Apoptosis and proliferation. In Situ Cell Death Detection Kit, POD (Roche Diagnostics, Basel, Switzerland) was used according to the manufacturer's instructions. The cells were analysed by light microscope. Six samples of control and MMP-8 + HSC-3, SCC-25 and SCC-15 cells were analysed. Cell Proliferation ELISA, BrdU (colorimetric) kit (Roche Diagnostics) was used with $1 \times 10^{4}$ control and MMP-8 + HSC-3 cells according to the manufacturer's instructions using eight technical replicates.

Cell migration and movement analyses. $4 \times 10^{4}$ control and MMP-8 + HSC-3 cells were seeded into 24-well plates with ibidi inserts (ibidi $\mathrm{GmbH}$, Martinsried, Germany). The next day the inserts were removed, the cells were washed with PBS and medium ( $1 \%$ FBS) was added. Phase-contrast time-lapse images were collected on an Olympus IX81 inverted microscope equipped with a $10 \times / 0.3$ objective and a grey-scale camera (Olympus XM10, Germany). The cells were maintained at $37^{\circ} \mathrm{C}$ and $5 \% \mathrm{CO}_{2}$ by a controlled microscope stage incubator (Okolab, Pozzuoli NA, Italy) mounted on the microscope. Images were acquired every $10 \mathrm{~min}$ for 
$12 \mathrm{~h}$ at multiple stage positions using a motorised stage (Prior) and Cell^P software (Soft imaging system $\mathrm{GmbH}$, Münster, Germany). Fiji software (Schindelin et al, 2012) was used to measure wound areas. For analyses of cell movement, cells were segmented from the time-lapse images using the maximally stable extremal regions approach (Matas et al, 2004). The Kalman filter-based multi-object tracking approach (Huttunen and Heikkilä, 2008) was used for tracking of the segmented cells. New tracks were initiated in each frame throughout the sequence to allow quantification of dynamic events taking place between successive frames. The analyses were performed with MATLAB (MathWorks, Natick, MA, USA). The application of the combination of the segmentation and tracking approaches for cell segmentation from phase-contrast images has been described in detail previously (Kaakinen et al, 2014). Six samples were studied for each cell group.

Transwell migration. Transwell inserts (Corning Inc., Corning, NY, USA) were stabilised with $600 \mu \mathrm{l}$ medium for $1 \mathrm{~h}$ and $5 \times 10^{4}$ control and MMP-8 + HSC-3 cells (two different clones) were seeded into the chambers in $(0.5 \%$ lactalbumin $)$ medium with and without $10 \mathrm{ng} \mathrm{ml}^{-1}$ TGF- $\beta 1$ (R\&D Systems). Similarly, the effect of $50 \mathrm{ng} \mathrm{ml}^{-1}$ VEGF-C (ProspecBio, Rehovot, Israel) was tested (one clone). After 24, 48 and $72 \mathrm{~h}$, the inserts were fixed with $4 \%$ formaldehyde, washed with PBS and stained with $1 \%$ Toluidine Blue $+1 \%$ sodium tetraborate in $\mathrm{ddH}_{2} \mathrm{O}$. After removing the excess dye with a cotton swab, the inserts were dipped in $1 \%$ SDS and the absorbances of three technical replicates were measured at $650 \mathrm{~nm}$.

Microarray. $9 \times 10^{4}$ control and MMP- $8+$ HSC-3 cells were seeded into six-well plates. The next day, three cultures per cell line were scratched throughout with a $1 \mathrm{ml}$ pipette tip at $\sim 2.5 \mathrm{~mm}$ intervals horizontally and vertically (migratory phenotype); three wells were left unwounded (stationary phenotype). Medium (1\% FBS) was added and after $10 \mathrm{~h}$ RNA was extracted by Qiagen RNA kit (Qiagen, Düsseldorf, Germany). Equal amounts of each RNA from the three cultures were pooled. Affymetrix GeneChip Human Genome U133 Plus 2.0 Arrays were used and the experimental procedures were performed according to the Affymetrix GeneChip Expression Analysis Technical Manual using $1 \mu \mathrm{g}$ of total RNA as template (see Supplementary Methods for more details). Finally, the arrays were scanned on a GeneChip Scanner 3000. dChip software (Li and Wong, 2001) was used for expression analyses (GEO, GSE85435) and DAVID 6.7 for Gene Ontology analyses (Dennis et al, 2003).

Zymography. Gelatin zymography was performed as described (Pirilä et al, 2007) with three different passages of control and MMP-8 + HSC-3 and SCC-25 cells.

TGF- $\beta 1$ ELISA. Human TGF-beta-1 Quantikine ELISA Kit (R\&D Systems) was used according to the kit protocol to measure TGF- $\beta 1$ levels in the conditioned media of control and MMP-8 + HSC-3 cells ( \pm acidic activation).

Patient samples. Paraffin-embedded archival resection specimens of OTSCC $(n=57)$ were obtained from the Department of Pathology, Oulu University Hospital. The patients had been diagnosed between the years 1984-2001. The survival data were acquired from Statistics Finland and other relevant data from the patient records. The baseline characteristics of the patients are presented in Supplementary Table S1. We were unable to retrieve treatment data of three patients and follow-up data of one patient. The use of the patient samples and the data inquiry were approved by the Ethics Committee of the Oulu University Hospital (\#49/ $2010,16.08 .2010)$ and by the National Supervisory Authority for Welfare and Health, Valvira (6865/05.01.00.06/2010, 05.10.2010).

Orthotopic mouse model of OTSCC. Cultured parental, control and MMP-8 + HSC-3 cells were detached and washed with medium. The cell suspensions in cold serum-free DMEM (Sigma-
Aldrich) were mixed with cold Matrigel $1: 1$ to a final concentra-

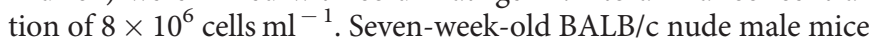
(Charles River, Germany) were anaesthetised with a mixture of $0.5 \mathrm{mg}$ ketamine and $0.1 \mathrm{mg}$ xylazine hydrochloride subcutaneously before $25 \mu \mathrm{l}$ of cell suspension $\left(2 \times 10^{5}\right.$ cells $)$ was injected into the lateral part of the tongue $(n=12$ for each of the cell clones). The mice were weighed daily and killed with $\mathrm{CO}_{2}$ if they lost more than $10 \%$ of their body weight or 13 days after the injection. Tongues and draining lymph nodes were fixed in $4 \%$ formalin immediately after removal. For positron emission tomography (PET) scanning, eight $( \pm 1)$ days after injections, three mice from parental and five mice from control and MMP$8+$ groups $(18.5 \mathrm{~g} \pm 1.8 \mathrm{~g})$ were used. While kept under constant anaesthesia, the mice were positioned with the head in the centre of the field of view inside the Triumph LabPET $-8^{\text {TM }}$ small animal PET/SPECT/CT scanner (Trifoil Imaging Inc., Chatsworth, CA, USA). More details of PET imaging are described in Supplementary Methods. All experiments complied with the ARRIVE guidelines and were conducted in accordance with the European Convention for the Protection of Vertebrate Animals for Experimental and Other Scientific Purposes' guidelines on accommodation and care of animals. The experiments were also approved by the Animal Welfare Committee at UiT-The Arctic University of Norway.

Histology and immunohistochemistry (IHC). Leiomyoma $(6 \mu \mathrm{m})$ and mouse tissue $(4 \mu \mathrm{m})$ samples were stained with Mayer's $\mathrm{H} \& \mathrm{E}$. The lymph nodes were investigated for metastatic foci at $100 \mu \mathrm{m}$ intervals. Immunohistochemistry with mouse anti-pancytokeratin AE1/AE3 antibody (Dako A/S), 1:150, was performed on leiomyoma tissue to identify carcinoma cells. Invasion was quantified as described (Nurmenniemi et al, 2009) using Fiji (Schindelin et al, 2012). The IHC staining of mouse anti-Ki-67, NCL-L-Ki67-MM1 (Novocastra Laboratories Ltd, Newcastle upon Tyne, UK), 1:100, mouse anti-E-cadherin \#13-1700 (Invitrogen), 1:300, mouse anti- $\mathrm{N}-$ cadherin 3B9, (Invitrogen), $1: 200$, and mouse anti-vimentin V9 (DAKO A/S, 1:1500, were performed similarly to pancytokeratin staining. IHC staining was done with a Dako Autostainer except for Ki-67 samples, which were incubated with primary antibody at $37^{\circ} \mathrm{C}$ for $30 \mathrm{~min}$ followed by incubation at $4^{\circ} \mathrm{C}$ overnight. Vectastain Elite $\mathrm{ABC}$ kit (Vector Laboratories Inc.) was used with the biotinylated secondary antibodies. DAB was used as a chromogen and the samples were counterstained with Mayer's haematoxylin. For staining of the mouse tumours, a heat-induced antigen retrieval $(10 \mathrm{~mm}$ citrate buffer $\mathrm{pH}$ 6.0) was performed. After blocking endogenous peroxidase activity (Peroxidase block, Dako, EnVision + system) and non-specific protein binding with normal goat serum, sections were incubated $1 \mathrm{~h}$ at room temperature with rabbit anti-MMP-8 monoclonal antibody EP1252Y (Abcam), 1:100. HRP-labelled secondary antibody and $\mathrm{DAB}$ were used for visualisation (EnVision + system-HRP for rabbit primary antibodies) before counterstaining with Harris Haematoxylin. Neutrophils were used as an internal positive control. The patient samples were selected on the basis of H\&E staining to be representative for the tumour mass in the resected specimen. Matrix metalloproteinase-8 (Hanemaaijer et al, 1997) immunostaining was performed as described (Korpi et al, 2008). VEGF-C staining was performed using goat anti-VEGFC antibody AF752 (R\&D Systems), 1:50. High-temperature antigen retrieval was performed in Tris-EDTA buffer for $15 \mathrm{~min}$ followed by Goat on Rodent HRP-Polymer (Biocare Medical, Concord, CA, USA) and with DAB as a chromogen. The samples were mounted in Glycergel (Dako A/S) or Aquamount (BDH Laboratory Supplies). Negative controls were omission of the primary antibody or replacement with an antibody isotype control.

Evaluation of IHC of OTSCC patient sample. Two independent researchers (JHK, TS), blinded from clinical data, evaluated the 
immunostained sections. The full evaluation of MMP-8 staining was described earlier (Korpi et al, 2008). The evaluation of VEGFC staining was performed using a two-point scale similar to that previously described (Shih et al, 2000; Shintani et al, 2004). Briefly, the percentage of positively stained cancer cells was counted and the cases were considered VEGF-C positive if more than $80 \%$ of the cells had positive cytoplasmic staining.

Statistical analysis. SPSS 18.0 software for Windows (SPSS Inc., Chicago, IL, USA) was used and a $P$-value $<0.05$ was considered statistically significant (indicated in the diagrams as ${ }^{\star} P<0.05$, $\left.{ }^{* *} P<0.01,{ }^{* * *} P<0.001\right)$. Student's $t$-test and Mann-Whitney $U$ test were used for comparisons of two independent groups and repeated measures ANOVA for dependent values at various time points. Pearson Chi-square test was used to calculate statistically significant differences between prognostic and clinicopathological variables. A correlation coefficient between MMP-8 and VEGF-C expression was calculated with Pearson's correlation coefficient. Life tables were calculated according to the Kaplan-Meier method. Survival curves were compared with the log-rank test. Uni- and multivariate survival analyses were done with the Cox proportional hazards model using the following covariates: VEGF-C and MMP8 co-expression (MMP-8 - /VEGF-C + or other), gender, age at the time of diagnosis $(<55,55-70$ and $>70$ years), tumour stages (1-2 and 3-4), tumour histologic grades (1,2 and 3) and adjuvant therapy (no adjuvant or radiotherapy). Multivariate analysis was done using backward stepwise selection of variables. A $P$-value of 0.05 was adopted as the limit for inclusion of a covariate. The backward stepwise algorithm was used to choose the best combination of prognostic factors to explain the mortality or recurrences in the study population. The hazard ratios (HRs) and 95\% CIs are provided for each covariate.

\section{RESULTS}

Overexpression of MMP-8 decreases invasion. Overexpression of MMP8 was confirmed by PCR and western blot (Figure 1A) and routinely checked. In case of HSC-3 cells, clone \#1 showed higher
A

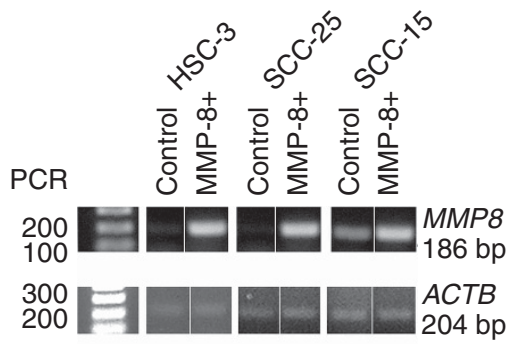

Western blot

70

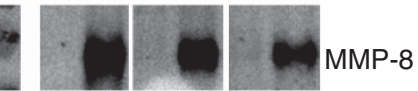

C

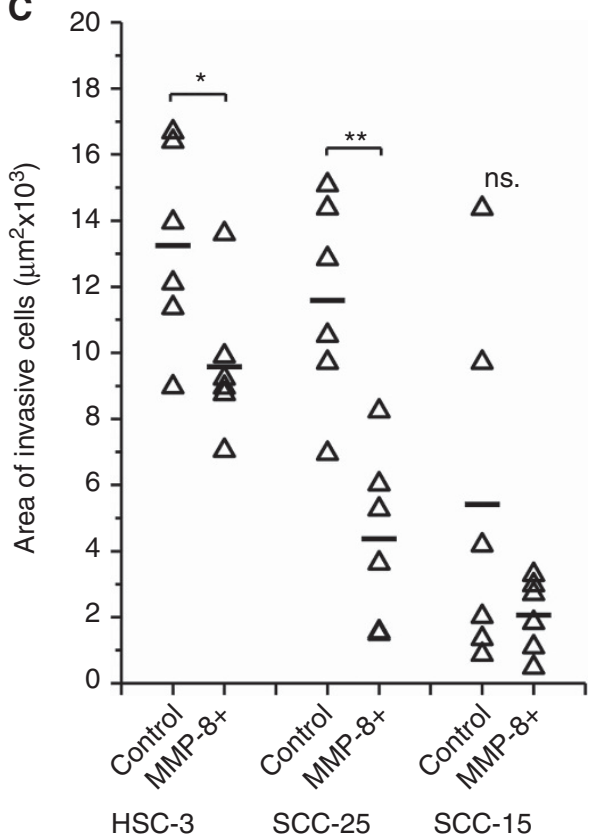

B
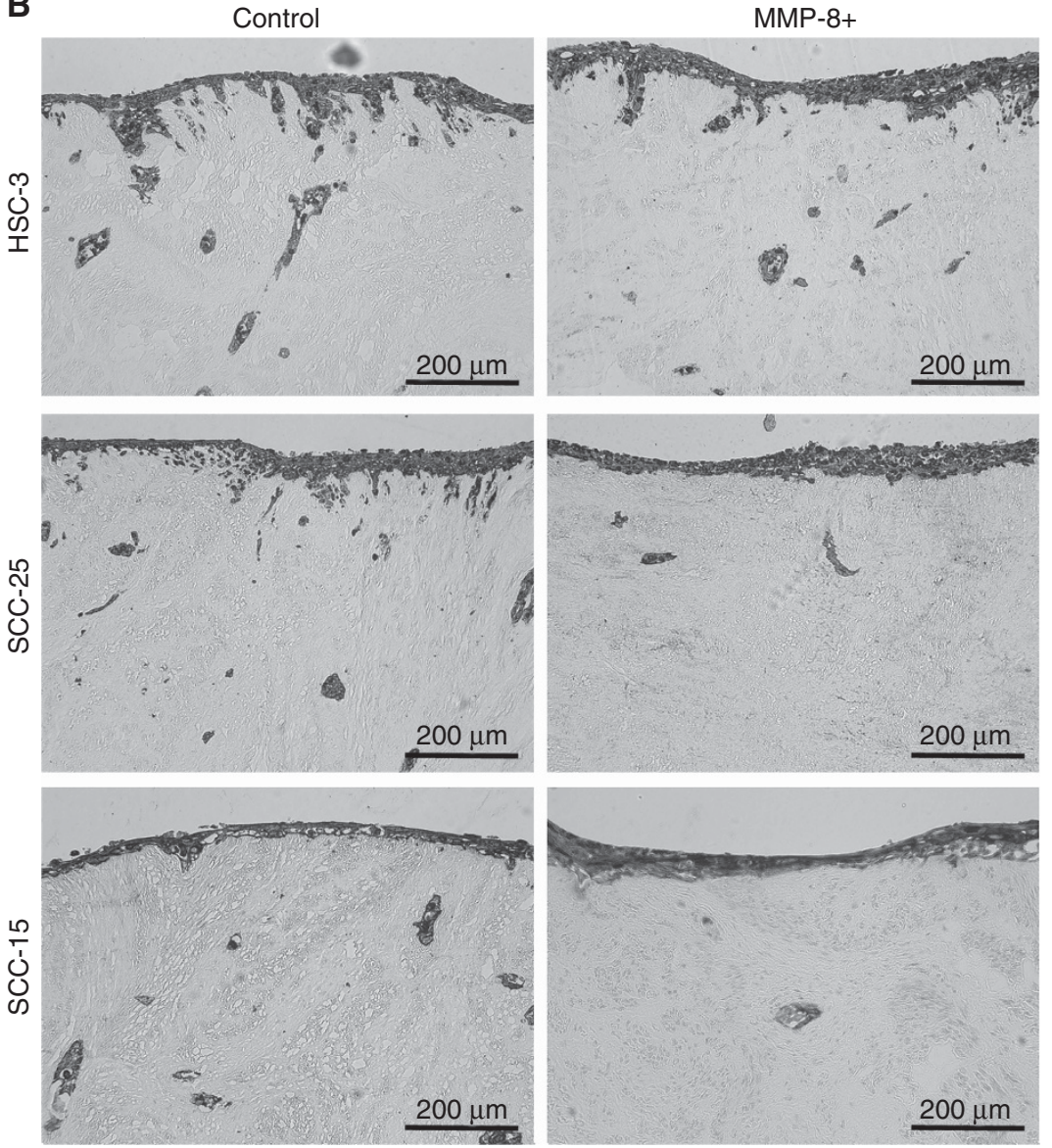

Figure 1. MMP-8 reduced the invasion of OTSCC cells. MMP8 gene expression and $\beta$-actin (ACTB) were measured from the same RT reaction samples. Overexpression of pro-MMP-8 was routinely confirmed by western blot from $20 \mu \mathrm{g}$ of conditioned media (representative result shown) (A). Organotypic 3D leiomyoma tissues were used to analyse cell invasion (B). The areas of invasive cytokeratin positive cells were quantified with Fiji software (C). ${ }^{\star} P<0.05,{ }^{\star}{ }^{*} P<0.01$, n.s. $=$ not significant. PCR was performed using samples from three different individual experiments (representative results shown). The myoma experiment was performed with duplicate leiomyoma disks per culture condition; three sections per disk were used in analyses. 
MMP-8 expression (Supplementary Figure S1A) and was used in experiments unless otherwise mentioned. Endogenous MMP8 expression was detected only in SCC-15 (Figure 1A). Based on protein size $(\sim 70 \mathrm{kDa})$, the detected band represents pro-MMP-8. The active form of MMP- 8 was detected in conditioned medium after treatment with APMA (Supplementary Figure S1B). The activation in cell culture conditions presumably occurs only temporally and locally. The overexpressed MMP-8 was functionally active, as demonstrated by radioimmunoassay with a higher concentration of the type I collagen degradation product ICTP $\left(0.63 \mu \mathrm{gl}^{-1}\right)$ in $(4 \times$ concentrated $)$ MMP- $8+$ conditioned medium compared to the control $\left(<0.25 \mu \mathrm{gl}^{-1}\right)$. The invasion of MMP-8 + HSC-3 $(P=0.037)$ and SCC-25 $(P=0.001)$ was reduced compared to controls (Figure $1 \mathrm{~B}$ and $\mathrm{C}$ ).

MMP-8 impairs migration. MMP-8 did not promote apoptosis (Supplementary Figure S2A). Among the epithelial to mesenchymal markers, only vimentin expression was slightly decreased in MMP-8 + HSC-3 cells (Supplementary Figure S2B). The change was also observed in the invasive areas of MMP- $8+$ cells in leiomyoma invasion assays (Supplementary Figure S2C). In further analyses, the two aggressive cell lines (HSC-3 and SCC-25) were used. Matrix metalloproteinase- 8 significantly suppressed the migration of HSC-3 cells $(P=0.015$; Figure $2 \mathrm{~A}$ and $\mathrm{B})$ by reducing both the number of moving cells $(P=0.015)$ and the magnitude of cell movement towards the empty area $(P=0.001$; Figure $2 \mathrm{C})$. The proliferation of MMP-8 + HSC-3 cells showed no difference (Supplementary Figure S2D; Ki-67 staining not shown).

MMP-8 affects the gene expression of various factors. To examine the overall effects of MMP-8, we compared the gene expression of stationary and migrating control and MMP-8+ HSC- 3 cells. The 20 most upregulated and downregulated genes and the genes that were changed only in stationary or migrating cells are shown in Supplementary Table S2 (fold change $\geqslant 1.5$ ). Supplementary Table S3 lists the genes involved in various cancerrelated events, including VEGFC, MMP1 and MMP9.

MMP-8 changes the proteinase web. We confirmed the decreased expression of MMP-1 and increased expression of MMP-9 at the protein level in HSC-3 and SCC-25 cells (Figure 3A and B). MMP$8+$ HSC-3 cells also expressed significantly $(P=0.002)$ lower levels of CTSK than control cells. Consistently, shCat-K HSC-3 cells expressed significantly $(P<0.001)$ increased levels of $M M P 8$ compared to controls (Figure $3 \mathrm{C}$ ). The expression of MMP-14 (MT1-MMP) was not changed (Figure 3D).

MMP-8 impairs VEGF-C expression and serves as prognostic tool together with VEGF-C. TGF- $\beta 1$ treatment increased VEGFC levels approximately 2.5 -fold in HSC-3 control cells. However, in only one of the three experiments with corresponding MMP-8 + HSC-3 cells was a slight increase observed (Figure 4A). This difference between control and MMP- $8+$ cells was not observed in HSC-3 clone \#2 probably due to its low MMP-8 overexpression (not shown). VEGF-C treatment did not revert the impaired migration of MMP-8 + HSC-3 cells (Transwell migration, not shown). The impaired (or even diminished) VEGF-C expression in TGF- $\beta 1$-treated MMP- $8+$ cells compared to control cells prompted us to examine the association of the two proteins in human OTSCC samples. We found that low expression of MMP-8 strongly correlated with high expression of VEGF-C $(\varphi=0.556$, $P<0.001)$. Both high VEGF-C and low MMP-8 expression levels associated with shortened cancer-specific survival $(P=0.001$ and $P=0.01$, respectively). However, the combined MMP-8 - /VEGF$\mathrm{C}+$-status was an even stronger predictor for poor cancer-specific survival $(P<0.001 ;$ Figure $4 \mathrm{~B})$. In multivariate analysis, the combined MMP-8-/VEGF-C + status was an independent predictor of cancer-specific deaths, with an HR of 7.157 (95\% confidence intervals (CIs) CI 2.219-23.082], along with high cancer stage and age over 70 at the time of the diagnosis (Figure 4C). Matrix metalloproteinase-8 and VEGF-C did not correlate with clinicopathological variables, except high VEGF-C expression was associated with lymph node metastasis (Supplementary Tables S1 and S4).

MMP-8 impairs migration via TGF- $\beta 1$ interference. Since TGF$\beta 1$ did not induce VEGF-C expression in MMP- $8+$ HSC- 3 cells as observed in control HSC-3 cells, we next examined its function in MMP- $8+$ cells. The relative level of the active TGF- $\beta 1$ was slightly reduced (n.s.) in MMP-8 + cells (Figure 5A). A transwell assay confirmed the impaired migration of MMP- $8+$ HSC-3 cells $(P=0.001$ after $48 \mathrm{~h}$ and $P=0.017$ after $72 \mathrm{~h}$, Figure $5 \mathrm{~B})$, which was also verified in clone \#2 (Supplementary Figure S3). TGF- $\beta 1$ treatment increased the migration of MMP- $8+$ HSC-3 cells, restoring the migration to the level of control cells after $72 \mathrm{~h}$ (Figure 5B). After $24 \mathrm{~h}$, both cell lines migrated more in the presence of TGF- $\beta 1$, but the difference in response to TGF- $\beta 1$ between the cell lines was not definite at that time point (data not shown). Differential effect of TGF- $\beta 1$ between control and MMP-8 + cells was observed in similar experiment performed with clone \#2 (Supplementary Figure S3). However, in this clone the effect was not as clear as in clone \#1 possibly due to substantially lower expression of MMP-8. The statistical analysis combining the average results of the different clones in transwell experiments or for other assays with two clones were not performed, because the resulting sample number would have been only two.

MMP-8 vanishes in tumour-stroma interface in mouse OTSCC. Lastly, we investigated whether overexpression of MMP-8 in HSC- 3 cells would reduce metastases in mouse OTSCC. Tumour take was $100 \%$ for all cell clones. The cell suspension was injected into the left side of the mouse tongue, confirmed by PET-imaging (Supplementary Figure S4A upper panel, more details in Supplementary Results, Supplementary Figure S4B and C). Cancer cells in tumours from the parental (Supplementary Figure S5A and B) and the control cell line (Supplementary Figure S5C and D) did not show any cytoplasmic MMP-8 staining. In the tumour islands with MMP-8 + cells, cytoplasmic staining of MMP- 8 was detected mainly in the most keratinised cells located in the centre of the tumour. In the tumour-stroma interface, the cancer cells showed weak or absent cytoplasmic MMP-8 staining (Supplementary Figure S5E and F). From the 13 mice killed at time point $8-9$ days, nine mice had lymph node metastases (included in the comparisons of the number of mice with and without metastases) (Supplementary Figure S6A and B). No significant difference in metastases was found between the groups (Supplementary Figure S6A-S6C).

\section{DISCUSSION}

Our study provides evidence for the tumour-suppressive mechanisms of MMP-8 in OTSCC by interplay with TGF- $\beta 1$ and VEGF-C. Previously identified protective actions of MMP-8 in cancers include the regulation of cell adhesion (GutiérrezFernández et al, 2008), inactivation of $\beta 1$-integrins (Pellinen et al, 2012), induction of interleukins 6 and 8 (Thirkettle et al, 2013) and inhibition of TGF- $\beta 1$ activity by decorin cleavage (SoriaValles et al, 2014). The invasiveness of the cell lines used in this study corresponded to the previously reported differences in their aggressiveness (HSC-3>SCC-25>SCC-15) (Scott et al, 1988; Ramos et al, 1997). Consistent with the previous studies (Agarwal et al, 2003; Montel et al, 2004), we found that MMP-8 reduces the invasion and migration of carcinoma cells. In melanoma and lung carcinoma, MMP-8 also prevented metastases (GutiérrezFernández et al, 2008). However, in the orthotopic mouse tongue 
A

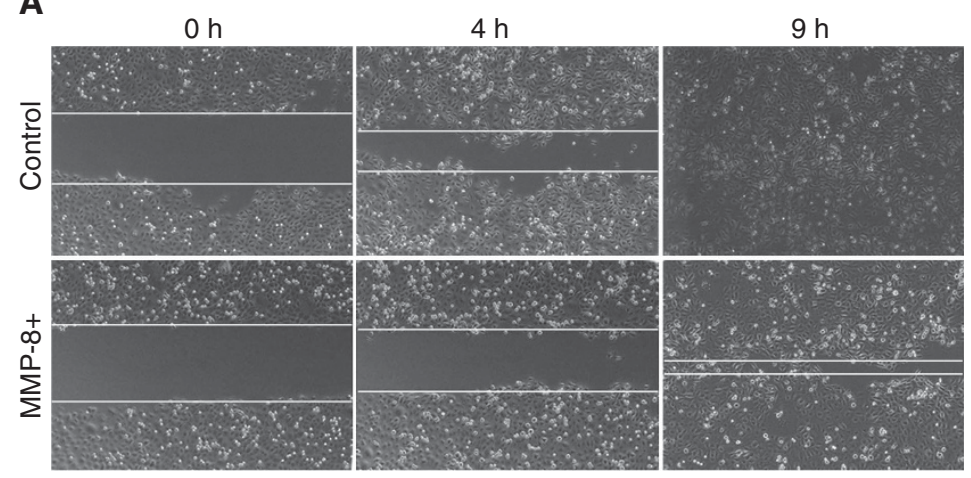

B

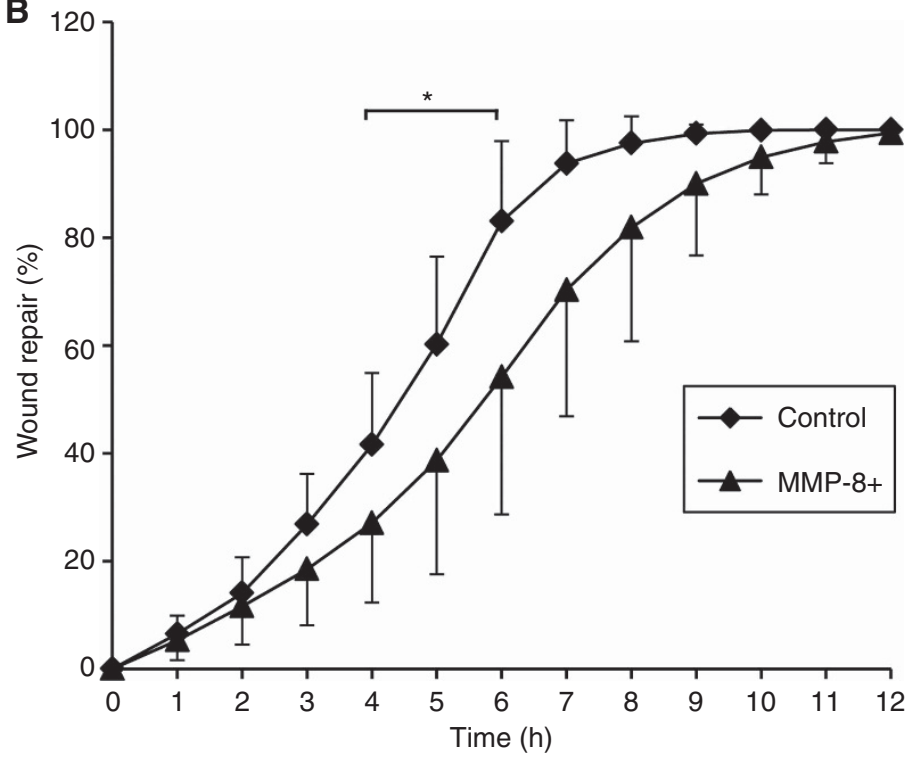

C
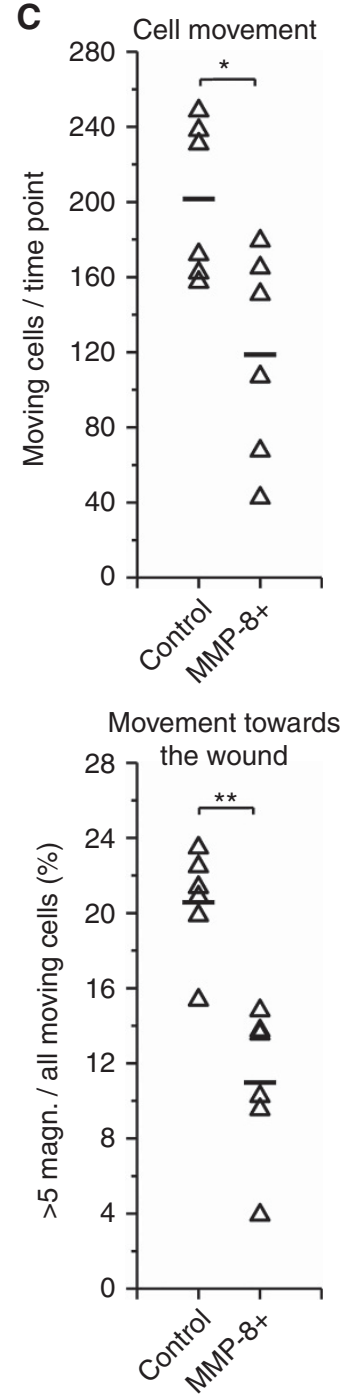

Figure 2. MMP-8 reduced the migration of HSC-3 cells. After removing the ibidi inserts, the migrating cells were photographed for $12 \mathrm{~h}(10 \mathrm{~min}$ intervals) (A). The open areas were measured using Fiji software and the results were calculated as a percentage of area closure (mean and standard deviation are shown) (B). Phase contrast time-lapse images were acquired at multiple stage positions using a motorised stage with Cell $\wedge \mathrm{P}$ software and the results were analysed using a Kalman filter-based tracking approach with MATLAB (C). ${ }^{\star} P<0.05,{ }^{\star \star} P<0.01$. Six replicates were analysed for each cell group in all experiments.

carcinoma model, the expression of MMP-8 almost completely vanished in the tumour periphery. The cells with low MMP-8 expression may have invasion and growth advantages in vivo, causing a shift in MMP-8 expression. Moreover, the complex in vivo setting in the tumour microenvironment may modulate the effects of MMP-8 via the presence of regulatory factors, such as tissue inhibitors of metalloproteinases. Downregulation of MMP- 8 in the tumour-stroma interface may have countered the possible oncosuppressive effects of MMP-8 in vivo, as the cells in the tumour periphery in particular contribute to invasion and metastasis.

Matrix metalloproteinase- 8 affects the level of MMP-3 in breast carcinoma (Decock et al, 2015). In OTSCC cells, MMP-8 overexpression decreased the expression of MMP-1, a tumourpromoting proteinase in OSCC (Sutinen et al, 1998; Kurahara et al, 1999; Jordan et al, 2004; Shimizu et al, 2008; George et al, 2010). Interestingly, MMP-9 expression was increased in MMP-8 + OTSCC cells. MMP-9 has both pro- and anti-tumourigenic roles in OSCC (Vilen et al, 2013). MMP-9 possesses antiangiogenic functions (Cornelius et al, 1998; Hamano et al, 2003; Bendrik et al, 2008) and is a negative prognostic factor when expressed by stromal cells but is a positive prognostic factor when expressed by cancer cells (Pellikainen et al, 2004; Mylona et al, 2007). The decreased expression of Cat-K in MMP-8 + HSC-3 cells is consistent with our previous study showing reduced invasion in shCat-K HSC-3 cells (Bitu et al, 2013). The mutual regulatory pathways between Cat-K and MMP-8 are unknown. Shared substrates, such as TGF- $\beta 1$ (Zhang et al, 2011; Åström et al, $2014)$, may participate in regulating proteinases. TGF- $\beta 1$ downregulates Cat-K (van den Brûle et al, 2005); both negative (Palosaari et al, 2000; Moilanen et al, 2002; Åström et al, 2014; Soria-Valles et al, 2014) and positive (Wen et al, 2015; Qin et al, 2016) regulatory pathways between MMP- 8 and TGF- $\beta 1$ have been reported. Our study provides further evidence for the mutual contribution of MMP- 8 and TGF- $\beta 1$ in cancer. Although a decreased level of active TGF- $\beta 1$ in MMP- $8+$ HSC- 3 cells was not statistically significant, it may be responsible for their reduced migration.

In macrophages, TGF- $\beta 1$ induces the expression of VEGF-C (Cursiefen et al, 2011), a tumour-promoting molecule involved in lymphangiogenesis (Karaman and Detmar, 2014). Our finding that MMP- 8 attenuates TGF- $\beta 1$ effects and blocks subsequent 
A

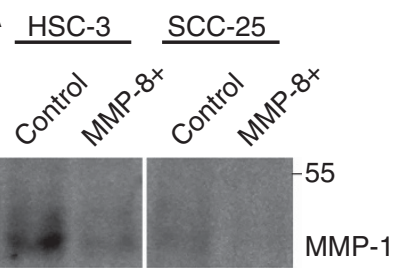

B

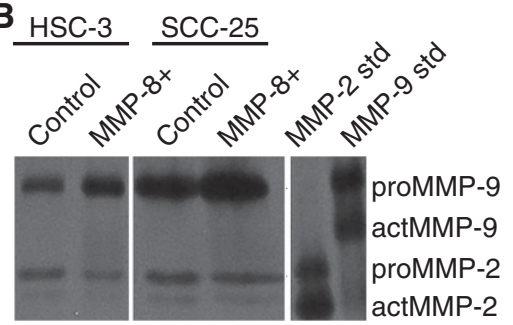

C

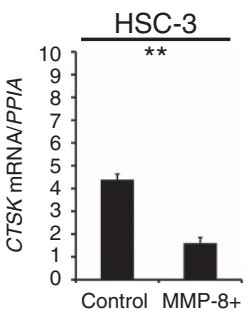

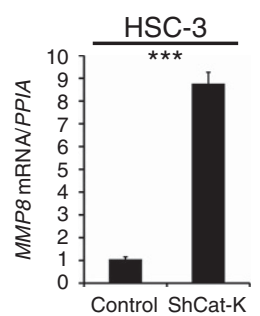

D

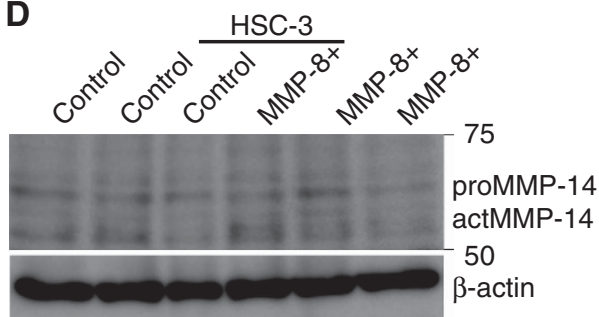

Figure 3. MMP-8 affected the expression levels of various proteinases. MMP- $8+$ HSC- 3 and SCC- 25 cells expressed less MMP- 1 than controls cells analysed by western blot from $20 \mu \mathrm{g}$ of conditioned media (A). The level of MMP-9 (but not MMP-2) was increased in conditioned media of MMP-8 + HSC-3 and SCC-25 cells analysed by zymography (B). Cathepsin-K (CTSK) mRNA levels were analysed from MMP-8 + and control HSC3 cells, and MMP8 mRNA levels from cathepsin K-silenced and control cells using real-time quantitative PCR (qRT-PCR). The $Y$ axis shows the ratio of CTSK or MMP-8 mRNA levels to the peptidylprolyl isomerase (PPIA) mRNA level (with standard deviations) (C). The level of MMP-14 was not changed in MMP-8 + HSC-3 cells as analysed by western blot from $40 \mu \mathrm{g}$ of cell protein extract (D). MMP-1 western blots and gelatin zymography were performed twice from two different individual experiments with HSC-3 and SCC-25 cells and qRT-PCRs in triplicates from two individual experiments. For MMP-14 western blot, three individual experiments of HSC-3 cells were analysed. ${ }^{* \star} P<0.01,{ }^{* \star *} P<0.001$.

A

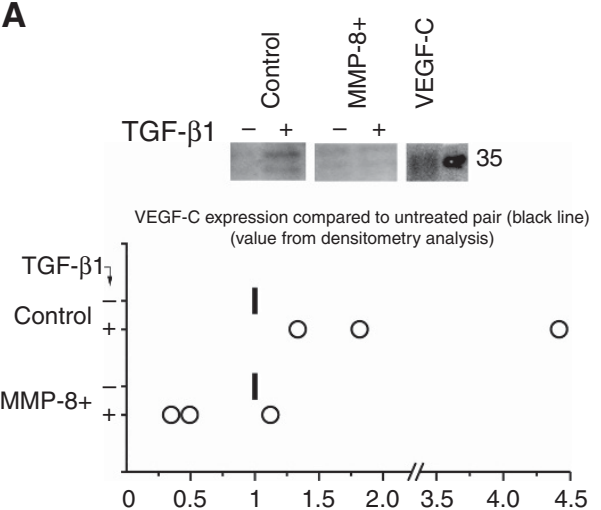

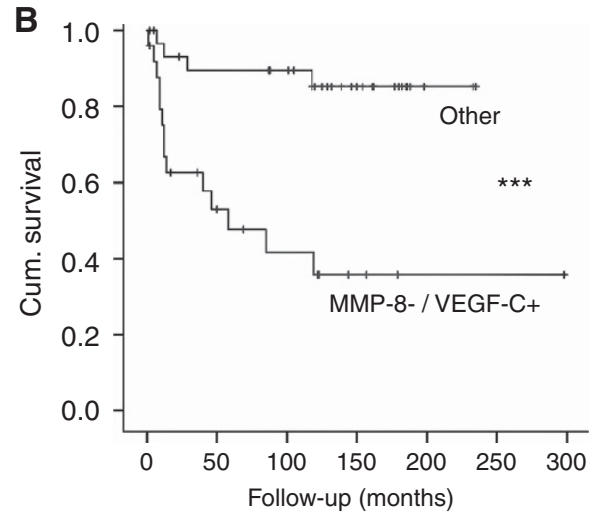

C Multivariate analysis: cancer mortality

\begin{tabular}{|c|c|c|c|}
\hline & & $\mathrm{HR}$ & $95 \% \mathrm{Cl}$ \\
\hline \multicolumn{4}{|l|}{ Age } \\
\hline & $<55$ years & 1.000 & \\
\hline & $55-70$ years & 0.481 & $0.091-2.536$ \\
\hline & $>70$ years & 4.589 & $1.393-15.119$ \\
\hline \multicolumn{4}{|c|}{ Tumour stage } \\
\hline & $1-2$ & 1.000 & \\
\hline & $3-4$ & 4.768 & $1.511-15.046$ \\
\hline \multicolumn{4}{|c|}{ MMP-8/VEGF-C-coexpression } \\
\hline & Other & 1.000 & \\
\hline & MMP-8-/VEGF-C+ & 7.157 & $2.219-23.082$ \\
\hline
\end{tabular}

Figure 4. MMP-8 overexpression blocked TGF- $\beta 1$-induced VEGF-C expression and low MMP-8/high VEGF-C associated with poor prognosis of OTSCC patients. VEGF-C was analysed by western blot from equal volumes of conditioned media (three individual experiments with different cell passages) with and without $10 \mathrm{ng} \mathrm{ml}^{-1}$ TGF- $\beta 1$. Representative samples are shown. The values from densitometer analyses (Fiji) were adjusted to the protein concentration of each media (A). VEGF-C and MMP-8 in OTSCC samples $(n=57)$ were detected by immunohistochemistry. The combined MMP-8 - NEGF-C + -status was highly predictive for poor cancer-specific survival as analysed by Kaplan-Meier method and compared with the other combinations (MMP-8 + NEGF-C +, MMP-8 + NEGF-C - or MMP-8 - NEGF-C - ) using the log-rank test $(P<0.001)(B)$.

Multivariate analysis was done using backward stepwise selection of variables, and a $P$-value of 0.05 was adopted as the limit for inclusion of a covariate. HRs, hazard ratios; $\mathrm{Cl}, 95 \%$ confidence interval (C). ${ }^{\star * \star} P<0.001$, log-rank test. 

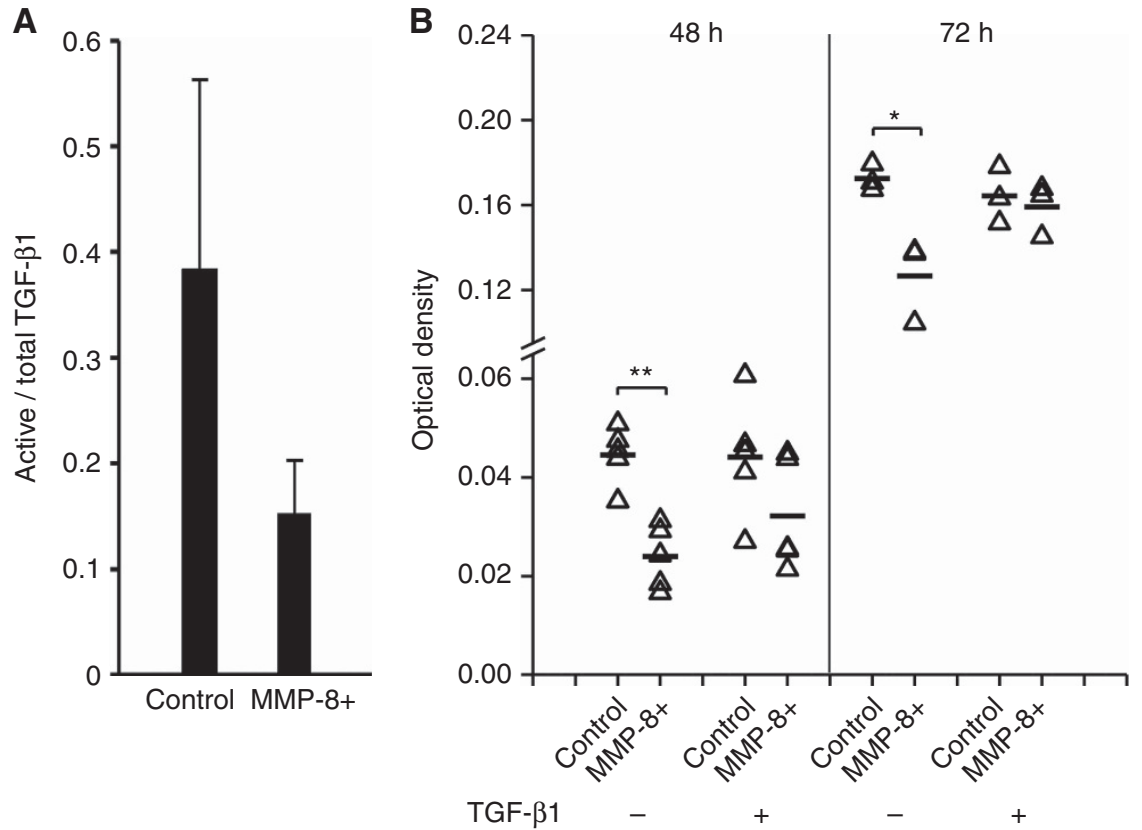

Figure 5. TGF- $\beta 1$ restored the reduced migration of MMP-8 + HSC-3 cells. ELISA was used to examine TGF- $\beta 1$ (active/total) in the conditioned media of MMP-8 + HSC-3 and control cells. TGF- $\beta 1$ concentrations were calculated per sample protein concentration and the percentage of the active form was calculated. The bars represent standard deviation (A). Recombinant human TGF- $\beta 1\left(10 \mathrm{ng} \mathrm{ml}{ }^{-1}\right)$ was added to the serum-free medium in the upper Transwell chamber and the amount of migrated MMP-8 + HSC-3 and control cells was measured as absorbance at $650 \mathrm{~nm}$ (B). ${ }^{\star} P<0.05,{ }^{\star} * P<0.01$. ELISA assay was performed using samples from three individual experiments and Transwell assay using five (48h) and three $(72 \mathrm{~h})$ samples.

VEGF-C expression in OTSCC cells is corroborated by the negative association of MMP-8 and VEGF-C in human OTSCC samples. In line with previous studies (O-charoenrat et al, 2001; Yanase et al, 2014), VEGF-C expression was associated with lymph node metastasis. Low MMP-8 and high VEGF-C have been separately linked to more aggressive OTSCC (Korpi et al, 2008; Siriwardena et al, 2008; Yanase et al, 2014), but the association of MMP-8 and VEGF-C and the strong and independent prognostic value of their combination have not been described before in OTSCC.

\section{ACKNOWLEDGEMENTS}

Mrs Maija-Leena Lehtonen, Mrs Eeva-Maija Kiljander, Mrs Pia Mäkelä, Mrs Anne Koskela, Mrs Erja Tomperi and Mrs Katja Koukkula are acknowledged for their excellent technical assistance. We thank Mr Tatu Pirkola for his guidance with Fiji, Ms Paula Pesonen for her help in statistical analyses, Dr Heta Merikallio for providing the Slug antibody, Dr Kaisa Lehti for providing the MMP-14 antibody and Dr Mika Kaakinen and Dr Sami Huttunen for their valuable guidance in cell movement analyses. We acknowledge the Biocenter Oulu Virus Core laboratory for providing their facilities and expertise in virus work. This research was funded by grants from the Academy of Finland \#135573, Sigrid Juselius Foundation, Finnish Cancer Foundation, research funds from the Medical Faculty of the University of Oulu and Oulu University Hospital special state support for research and Medical Research Center Oulu (TS), Finnish Doctoral Program in Oral Sciences, FINDOS, Ida Montin Foundation, Tyyni Tani Foundation (PA), Finnish Dental Society Apollonia (MS), Cancer Foundation of Northern Ostrobothnia (PA, MS, JHK), Oulu University Research Foundation, Emil Aaltonen Foundation, Mary and Georg C. Ehrnroot Foundation and Finnish Medical Foundation (JHK).

\section{CONFLICT OF INTEREST}

The authors declare no conflict of interest.

\section{REFERENCES}

Agarwal D, Goodison S, Nicholson B, Tarin D, Urquidi V (2003) Expression of matrix metalloproteinase 8 (MMP-8) and tyrosinase-related protein-1 (TYRP-1) correlates with the absence of metastasis in an isogenic human breast cancer model. Differentiation 71: 114-125.

Åström P, Pirilä E, Lithovius R, Heikkola H, Korpi JT, Hernandez M, Sorsa T, Salo T (2014) Matrix metalloproteinase- 8 regulates transforming growth factor-beta1 levels in mouse tongue wounds and fibroblasts in vitro. Exp Cell Res 328: 217-227.

Balbin M, Fueyo A, Tester AM, Pendas AM, Pitiot AS, Astudillo A, Overall CM, Shapiro SD, Lopez-Otin C (2003) Loss of collagenase-2 confers increased skin tumor susceptibility to male mice. Nat Genet 35 : 252-257.

Bendrik C, Robertson J, Gauldie J, Dabrosin C (2008) Gene transfer of matrix metalloproteinase- 9 induces tumor regression of breast cancer in vivo. Cancer Res 68: 3405-3412.

Bitu CC, Kauppila JH, Bufalino A, Nurmenniemi S, Teppo S, Keinänen M, Vilen ST, Lehenkari P, Nyberg P, Coletta RD, Salo T (2013) Cathepsin K is present in invasive oral tongue squamous cell carcinoma in vivo and in vitro. PLoS One 8: e70925.

van den Brûle S, Misson P, Bühling F, Lison D, Huaux F (2005) Overexpression of cathepsin $\mathrm{K}$ during silica-induced lung fibrosis and control by TGF- $\beta$. Respir Res 6: 84 .

Cornelius LA, Nehring LC, Harding E, Bolanowski M, Welgus HG, Kobayashi DK, Pierce RA, Shapiro SD (1998) Matrix metalloproteinases generate angiostatin: effects on neovascularization. J Immunol 161: 6845-6852.

Cursiefen C, Maruyama K, Bock F, Saban D, Sadrai Z, Lawler J, Dana R, Masli S (2011) Thrombospondin 1 inhibits inflammatory lymphangiogenesis by CD36 ligation on monocytes. J Exp Med 208: 1083-1092.

Decock J, Hendrickx W, Thirkettle S, Gutiérrez-Fernández A, Robinson SD, Edwards DR (2015) Pleiotropic functions of the tumor- and 
metastasis-suppressing matrix metalloproteinase-8 in mammary cancer in MMTV-PyMT transgenic mice. Breast Cancer Res 17: 38.

Decock J, Hendrickx W, Vanleeuw U, Van Belle V, Van Huffel S, Christiaens MR, Ye S, Paridaens R (2008) Plasma MMP1 and MMP8 expression in breast cancer: protective role of MMP8 against lymph node metastasis. BMC Cancer 8: 77-2407-8-77.

Dennis Jr G, Sherman BT, Hosack DA, Yang J, Gao W, Lane HC, Lempicki RA (2003) DAVID: database for annotation, visualization, and integrated discovery. Genome Biol 4: P3.

Egeblad M, Werb Z (2002) New functions for the matrix metalloproteinases in cancer progression. Nat Rev Cancer 2: 161-174.

George A, Ranganathan K, Rao UK (2010) Expression of MMP-1 in histopathological different grades of oral squamous cell carcinoma and in normal buccal mucosa - an immunohistochemical study. Cancer Biomark 7: 275-283.

Gutiérrez-Fernández A, Fueyo A, Folgueras AR, Garabaya C, Pennington CJ, Pilgrim S, Edwards DR, Holliday DL, Jones JL, Span PN, Sweep FC, Puente XS, Lòpez-Otín C (2008) Matrix metalloproteinase-8 functions as a metastasis suppressor through modulation of tumor cell adhesion and invasion. Cancer Res 68: 2755-2763.

Hamano Y, Zeisberg M, Sugimoto H, Lively JC, Maeshima Y, Yang C, Hynes RO, Werb Z, Sudhakar A, Kalluri R (2003) Physiological levels of tumstatin, a fragment of collagen IV alpha3 chain, are generated by MMP-9 proteolysis and suppress angiogenesis via alphaV beta3 integrin. Cancer Cell 3: 589-601.

Hanemaaijer R, Sorsa T, Konttinen YT, Ding Y, Sutinen M, Visser H, van Hinsbergh VW, Helaakoski T, Kainulainen T, Rönkä $H$, Tschesche H, Salo T (1997) Matrix metalloproteinase- 8 is expressed in rheumatoid synovial fibroblasts and endothelial cells. Regulation by tumor necrosis factor-alpha and doxycycline. J Biol Chem 272: 31504-31509.

Huttunen S, Heikkilä J (2008) Multi-object tracking using binary masks. In IEEE International Conference on Image Processing, pp 2640-2643. IEEE: San Diego, CA, USA.

Jordan RC, Macabeo-Ong M, Shiboski CH, Dekker N, Ginzinger DG, Wong DT, Schmidt BL (2004) Overexpression of matrix metalloproteinase-1 and -9 mRNA is associated with progression of oral dysplasia to cancer. Clin Cancer Res 10: 6460-6465.

Kaakinen M, Huttunen S, Paavolainen L, Marjomäki V, Heikkilä J, Eklund L (2014) Automatic detection and analysis of cell motility in phase-contrast time-lapse images using a combination of maximally stable extremal regions and Kalman filter approaches. J Microsc 253: 65-78.

Karaman S, Detmar M (2014) Mechanisms of lymphatic metastasis. J Clin Invest 124: 922-928.

Korpi JT, Kervinen V, Mäklin H, Väänänen A, Lahtinen M, Läärä E, Ristimäki A, Thomas G, Ylipalosaari M, Åström P, Lopez-Otin C, Sorsa T, Kantola S, Pirilä E, Salo T (2008) Collagenase-2 (matrix metalloproteinase-8) plays a protective role in tongue cancer. Br J Cancer 98: 766-775.

Kurahara S, Shinohara M, Ikebe T, Nakamura S, Beppu M, Hiraki A, Takeuchi H, Shirasuna K (1999) Expression of MMPS, MT-MMP, and TIMPs in squamous cell carcinoma of the oral cavity: correlations with tumor invasion and metastasis. Head Neck 21: 627-638.

Li C, Wong WH (2001) Model-based analysis of oligonucleotide arrays: expression index computation and outlier detection. Proc Natl Acad Sci USA 98: 31-36.

Mäkinen LK, Häyry V, Atula T, Haglund C, Keski-Säntti H, Leivo I, Mäkitie A, Passador-Santos F, Bockelman C, Salo T, Sorsa T, Hagström J (2012) Prognostic significance of matrix metalloproteinase-2, $-8,-9$, and -13 in oral tongue cancer. J Oral Pathol Med 41: 394-399.

Matas J, Chum O, Urban M, Pajdla T (2004) Robust wide-baseline stereo from maximally stable extremal region. Image Vis Comput 22: 761-767.

Moilanen M, Pirilä E, Grenman R, Sorsa T, Salo T (2002) Expression and regulation of collagenase-2 (MMP-8) in head and neck squamous cell carcinomas. J Pathol 197: 72-81.

Montel V, Kleeman J, Agarwal D, Spinella D, Kawai K, Tarin D (2004) Altered metastatic behavior of human breast cancer cells after experimental manipulation of matrix metalloproteinase 8 gene expression. Cancer Res 64: 1687-1694.

Mylona E, Nomikos A, Magkou C, Kamberou M, Papassideri I, Keramopoulos A, Nakopoulou L (2007) The clinicopathological and prognostic significance of membrane type 1 matrix metalloproteinase (MT1-MMP) and MMP-9 according to their localization in invasive breast carcinoma. Histopathology 50: 338-347.
Nurmenniemi S, Koivula MK, Nyberg P, Tervahartiala T, Sorsa T, Mattila PS, Salo T, Risteli J (2012) Type I and III collagen degradation products in serum predict patient survival in head and neck squamous cell carcinoma. Oral Oncol 48: 136-140.

Nurmenniemi S, Sinikumpu T, Alahuhta I, Salo S, Sutinen M, Santala M, Risteli J, Nyberg P, Salo T (2009) A novel organotypic model mimics the tumor microenvironment. Am J Pathol 175: 1281-1291.

O-charoenrat P, Rhys-Evans P, Eccles SA (2001) Expression of vascular endothelial growth factor family members in head and neck squamous cell carcinoma correlates with lymph node metastasis. Cancer 92: 556-568.

Overall CM, Kleifeld O (2006) Towards third generation matrix metalloproteinase inhibitors for cancer therapy. Br J Cancer 94: 941-946.

Palavalli LH, Prickett TD, Wunderlich JR, Wei X, Burrell AS, Porter-Gill P, Davis S, Wang C, Cronin JC, Agrawal NS, Lin JC, Westbroek W, Hoogstraten-Miller S, Molinolo AA, Fetsch P, Filie AC, O'Connell MP, Banister CE, Howard JD, Buckhaults P, Weeraratna AT, Brody LC, Rosenberg SA, Samuels Y (2009) Analysis of the matrix metalloproteinase family reveals that MMP8 is often mutated in melanoma. Nat Genet $\mathbf{4 1}$ : 518-520.

Palosaari H, Wahlgren J, Larmas M, Rönkä H, Sorsa T, Salo T, Tjäderhane L (2000) The expression of MMP-8 in human odontoblasts and dental pulp cells is down-regulated by TGF-beta1. J Dent Res 79: 77-84.

Pellikainen JM, Ropponen KM, Kataja VV, Kellokoski JK, Eskelinen MJ, Kosma VM (2004) Expression of matrix metalloproteinase (MMP)-2 and MMP-9 in breast cancer with a special reference to activator protein-2, HER2, and prognosis. Clin Cancer Res 10: 7621-7628.

Pellinen T, Rantala JK, Arjonen A, Mpindi JP, Kallioniemi O, Ivaska J (2012) A functional genetic screen reveals new regulators of beta1-integrin activity. J Cell Sci 125: 649-661.

Pirilä E, Korpi JT, Korkiamäki T, Jahkola T, Gutiérrez-Fernández A, Lòpez-Otín C, Saarialho-Kere U, Salo T, Sorsa T (2007) Collagenase-2 (MMP-8) and matrilysin-2 (MMP-26) expression in human wounds of different etiologies. Wound Repair Regen 15: 47-57.

Pradhan-Palikhe P, Vesterinen T, Tarkkanen J, Leivo I, Sorsa T, Salo T, Mattila PS (2010) Plasma level of tissue inhibitor of matrix metalloproteinase- 1 but not that of matrix metalloproteinase- 8 predicts survival in head and neck squamous cell cancer. Oral Oncol 46: 514-518.

Qin G, Luo M, Chen J, Dang Y, Chen G, Li L, Zeng J, Lu Y, Yang J (2016) Reciprocal activation between MMP-8 and TGF- $\beta 1$ stimulates EMT and malignant progression of hepatocellular carcinoma. Cancer Lett 374: 85-95.

Ramos DM, Chen BL, Boylen K, Stern M, Kramer RH, Sheppard D, Nishimura SL, Greenspan D, Zardi L, Pytela R (1997) Stromal fibroblasts influence oral squamous-cell carcinoma cell interactions with tenascin-C. Int J Cancer 72: 369-376.

Rethman MP, Carpenter W, Cohen EE, Epstein J, Evans CA, Flaitz CM, Graham FJ, Hujoel PP, Kalmar JR, Koch WM, Lambert PM, Lingen MW, Oettmeier Jr BW, Patton LL, Perkins D, Reid BC, Sciubba JJ, Tomar SL, Wyatt Jr AD, Aravamudhan K, Frantsve-Hawley J, Cleveland JL, Meyer DM. American Dental Association Council on Scientific Affairs Expert Panel on Screening for Oral Squamous Cell Carcinomas (2010) Evidence-based clinical recommendations regarding screening for oral squamous cell carcinomas. J Am Dent Assoc 141: 509-520.

Risteli J, Elomaa I, Niemi S, Novamo A, Risteli L (1993) Radioimmunoassay for the pyridinoline cross-linked carboxy-terminal telopeptide of type I collagen: a new serum marker of bone collagen degradation. Clin Chem 39: 635-640.

Schindelin J, Arganda-Carreras I, Frise E, Kaynig V, Longair M, Pietzsch T, Preibisch S, Rueden C, Saalfeld S, Schmid B, Tinevez JY, White DJ, Hartenstein V, Eliceiri K, Tomancak P, Cardona A (2012) Fiji: an opensource platform for biological-image analysis. Nat Methods 9: 676-682.

Scott RE, Wilke MS, Wille Jr JJ, Pittelkow MR, Hsu BM, Kasperbauer JL (1988) Human squamous carcinoma cells express complex defects in the control of proliferation and differentiation. Am J Pathol 133: 374-380.

Shih CH, Ozawa S, Ando N, Ueda M, Kitajima M (2000) Vascular endothelial growth factor expression predicts outcome and lymph node metastasis in squamous cell carcinoma of the esophagus. Clin Cancer Res 6: 1161-1168.

Shimizu Y, Kondo S, Shirai A, Furukawa M, Yoshizaki T (2008) A single nucleotide polymorphism in the matrix metalloproteinase- 1 and interleukin-8 gene promoter predicts poor prognosis in tongue cancer. Auris Nasus Larynx 35: 381-389.

Shintani S, Li C, Ishikawa T, Mihara M, Nakashiro K, Hamakawa H (2004) Expression of vascular endothelial growth factor A, B, C, and D in oral squamous cell carcinoma. Oral Oncol 40: 13-20. 
Siriwardena BS, Kudo Y, Ogawa I, Udagama MN, Tilakaratne WM, Takata T (2008) VEGF-C is associated with lymphatic status and invasion in oral cancer. J Clin Pathol 61: 103-108.

Soria-Valles C, Gutiérrez-Fernández A, Guiu M, Mari B, Fueyo A, Gomis RR, Lòpez-Otín C (2014) The anti-metastatic activity of collagenase-2 in breast cancer cells is mediated by a signaling pathway involving decorin and miR-21. Oncogene 33: 3054-3063.

Stadlmann S, Pollheimer J, Moser PL, Raggi A, Amberger A, Margreiter R, Offner FA, Mikuz G, Dirnhofer S, Moch H (2003) Cytokine-regulated expression of collagenase-2 (MMP-8) is involved in the progression of ovarian cancer. Eur J Cancer 39: 2499-2505.

Sutinen M, Kainulainen T, Hurskainen T, Vesterlund E, Alexander JP, Overall CM, Sorsa T, Salo T (1998) Expression of matrix metalloproteinases (MMP-1 and -2) and their inhibitors (TIMP-1, -2 and -3 ) in oral lichen planus, dysplasia, squamous cell carcinoma and lymph node metastasis. $\mathrm{Br} J$ Cancer 77: 2239-2245.

Teppo S, Sundquist E, Vered M, Holappa H, Parkkisenniemi J, Rinaldi T, Lehenkari P, Grenman R, Dayan D, Risteli J, Salo T, Nyberg P (2013) The hypoxic tumor microenvironment regulates invasion of aggressive oral carcinoma cells. Exp Cell Res 319: 376-389.

Thirkettle S, Decock J, Arnold H, Pennington CJ, Jaworski DM, Edwards DR (2013) Matrix metalloproteinase 8 (collagenase 2) induces the expression of interleukins 6 and 8 in breast cancer cells. J Biol Chem 288: 16282-16294.
Van Lint P, Libert C (2006) Matrix metalloproteinase-8: cleavage can be decisive. Cytokine Growth Factor Rev 17: 217-223.

Väyrynen JP, Vornanen J, Tervahartiala T, Sorsa T, Bloigu R, Salo T, Tuomisto A, Mäkinen MJ (2012) Serum MMP-8 levels increase in colorectal cancer and correlate with disease course and inflammatory properties of primary tumors. Int J Cancer 131: E463-E474.

Vilen ST, Salo T, Sorsa T, Nyberg P (2013) Fluctuating roles of matrix metalloproteinase-9 in oral squamous cell carcinoma. ScientificWorldJournal 2013: 920595.

Wen G, Zhang C, Chen Q, Luong Ie A, Mustafa A, Ye S, Xiao Q (2015) A novel role of matrix metalloproteinase- 8 in macrophage differentiation and polarization. J Biol Chem 290: 19158-19172.

Yanase M, Kato K, Yoshizawa K, Noguchi N, Kitahara H, Nakamura H (2014) Prognostic value of vascular endothelial growth factors A and C in oral squamous cell carcinoma. J Oral Pathol Med 43: 514-520.

Zhang D, Leung N, Weber E, Saftig P, Brömme D (2011) The effect of cathepsin K deficiency on airway development and TGF- $\beta 1$ degradation. Respir Res 12: 72.

This work is published under the standard license to publish agreement. After 12 months the work will become freely available and the license terms will switch to a Creative Commons AttributionNonCommercial-Share Alike 4.0 Unported License.

${ }^{1}$ Cancer and Translational Medicine Research Unit, University of Oulu, PO Box 5281, Oulu 90014, Finland; ${ }^{2}$ Medical Research Center Oulu, Oulu 90220, Finland; ${ }^{3}$ Oulu University Hospital, Oulu 90220, Finland; ${ }^{4}$ Department of Medical Biology, Faculty of Health Sciences, UiT - The Arctic University of Norway, Tromsø, Tromsø 9037, Norway; ${ }^{5}$ Department of Morphology and Basic Pathology, Faculty of Medicine of Jundiai (FMJ), Jundiai, São Paulo, Brazil; ' ${ }^{6}$ Department of Oral Diagnosis, School of Dentistry, State University of Campinas, Av. Limeira 901, CEP 13414-018, Piracicaba-SP, Brazil; ${ }^{7}$ Department of Clinical Chemistry, University of Oulu, Oulu PO Box 5000, 90014, Finland; ${ }^{8}$ Northern Finland Laboratory Centre NordLab, Oulu University Hospital, Oulu 90220 , Finland; ' Upper Gastrointestinal Surgery, Department of Molecular Medicine and Surgery, Karolinska Institutet, Karolinska University Hospital, Stockholm SE-171 76, Sweden; ${ }^{10}$ Faculty of Biochemistry and Molecular Medicine, University of Oulu, Oulu 90014, Finland; ${ }^{11}$ Biocenter Oulu, University of Oulu, Oulu 90014, Finland; ${ }^{12}$ Center for Life Course Health Research, Faculty of Medicine, PO Box 5000, University of Oulu, Oulu 90014, Finland; ${ }^{13}$ Medical Imaging Research Group, Department of Clinical Medicine, Faculty of Health Sciences, University of Tromsø - the Arctic University of Norway, 9037 Troms $\varnothing$, Norway; ${ }^{14}$ Department of Radiology and Nuclear Medicine, University Hospital of North Norway, Tromsø 9038, Norway; ${ }^{15}$ Helsinki University Central Hospital, Helsinki, Finland and ${ }^{16}$ Department of Oral Pathology, Institute of Dentistry, Biomedicum, PO Box 63, University of Helsinki, Helsinki 00014, Finland

Supplementary Information accompanies this paper on British Journal of Cancer website (http://www.nature.com/bjc) 